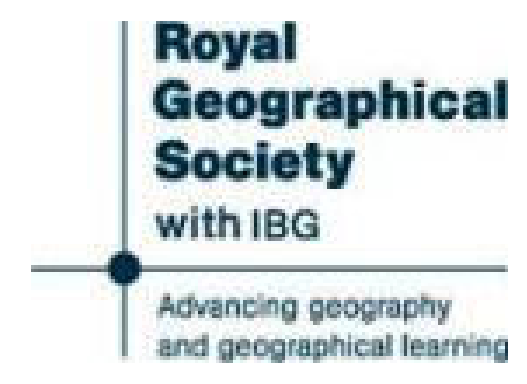

The Recent Crinoids and Their Relation to Sea and Land Author(s): Austin Hobart Clark

Source: The Geographical Journal, Vol. 32, No. 6 (Dec., 1908), pp. 602-607

Published by: The Royal Geographical Society (with the Institute of British Geographers)

Stable URL: http://www.jstor.org/stable/1777525

Accessed: 17/02/2015 21:39

Your use of the JSTOR archive indicates your acceptance of the Terms \& Conditions of Use, available at

http://www.jstor.org/page/info/about/policies/terms.jsp

JSTOR is a not-for-profit service that helps scholars, researchers, and students discover, use, and build upon a wide range of content in a trusted digital archive. We use information technology and tools to increase productivity and facilitate new forms of scholarship. For more information about JSTOR, please contact support@ jstor.org. 


\section{THE RECENT CRINOIDS AND THEIR RELATION TO SEA AND LAND.*}

\section{BY AUSTIN HOBART CLARK.}

Although long known as an important group from a palæontological standpoint, it was not until the publication of Dr. P. H. Carpenter's two monographs in the Challenger reports in 1884 and 1883 that the crinoids were accorded their rightful position as one of the most important classes of marine invertebrates inhabiting the recent seas, a position unique among the creatures of the sea in its relation to questions of geography and thalassography, as well as to geolngy. Crinoids, as a class, are probably the most strictly sessile of all marine organisms; many of them are stalked and cannot move, and those forms in which the stalk is partially or entirely lost in adult life probably move but very seldom, and not at all unless under strong compulsion. Their free-swimming larval period (so far as we know) is of short duration; the larva soon sinks to the bottom, and becomes fixed. The depth at which most of them live renders them secure from the influence of surface currents; hence we should be able to learn much of value from their distribution upon the sea bottom which we could not gather from the history of any other group. There is no record of crinoid larva, other than those of littoral species, having been taken at or near the surface, though I have taken the post-larval stages of ophiuroids and asteroids from shrimps in the Bering sea, caught at the surface over depths of several hundred fathoms. The asteroids and ophiuroids are bottom animals, but the occurrence of their yourg, in considerable numbers, at the surface indicates a power of dispersal quite unattainable by the crinoids. The extraordinary development of an inorganic skeleton within the crinoid body renders it peculiarly susceptible to preservation as a fossil, bence their great geological importance, an importance which, considering the class as a whole, is increased by the fact that, so far as we know, there are no soft-bodied forms among them.

Geographically and bathymetrically, the recent crinoids fall into three wellmarked faunæ, as follows :-

1. Indo-Pacific Japanese, extending from East Africa (Madagascar to the Red sea) eastward, including the southern shores of Asia and all the coasts of Australia, the South sea islands generally, and thence northward to southern Japan. Hawaii, the Galapagos islands, and the Pacific coast of South America are not included. The characteristic species are almost all, at least among the unstalked forms, littoral or shallow-water types; they include all the species of Zygometrida and Himerometridx; the species of the genera Comatula, Phanogenia, and most of those of Comaster of the Comasteridæ; Ptilometra, Asterometra, Calometra, and one of the two species of Tropiometra of the Tropiometridæ; and the species of Perometra, Nanometra, Compsometra, Thysanometra, and Iridometra of the Antedonidæ. Among the stalked crinoids Metacrinus, Carpenterocrinus, Hypalocrinus, and Phrynocrinus are only known from this region.

2. Oceanic, a well-differentiated offshoot from the preceding, and occurring everywhere with it and thence over the entire ocean area, except that it is never found with the succeeding; it inhabits deep water only, from approximately 400 to 2900 fathoms.

Characteristic of this fauna are the species of Thalassometra having rounded

* The names used throughout this article will be found explained in the author's paper on "The Nomenclature of the Recent Crinoids," Proc. U.S. National Museum, vel. 34, pp. 435-542. 
and spiny rays and arm bases (such as T. bispinosa, T. villosa, T. gigantea, T. pubescens, T.aster, T. echinata, and T. multispina), and certain other spocies such as T. flava, T. porrecta, and T. magnicirra, Stylometra, Bathymetra, and Charitometra, except the aculeata, hepburniana, basicurva, and tuberosa groups; of stalked forms Rhizocrinus, Endoxocrinus, and the species of Bathycrinus except the $B$. carpenterii group belong here. The crinoids of Hawaii and the Galapagos, all from deep water, are members of this division, as are also those of the West Indies, though a few from the last-mentioned locality suggest affinities which it is not worth while to discuss here.

3. Polar-Pacific, embracing the Arctic and Antarctic seas, and the entire Pacific coast of North and South America; in the Atlantic this fauna extends southward to near the Hebrides and the Faroë channel, and to Halifax; in the Pacific it includes the Okhotsk and Japanese seas, and the eastern coast of Japan to Tokyo bay. The Polar-Pacific area is divisible into two well-marked sections, the Arctic, including the Arctic regions and the North Atlantic, and the Okhotsk and Japanese seas; and the Antarctic, including the Antarctic regions, and the eastern, northern (including Bering sea), and north-western Pacific, but not entering the seas of Okhotsk or Japan.

The unstalked crinoids occurring here belong exclusively to the Antedonidæ; Heliometra occurs everywhere; Thaumatometra and Isometra are found in the Antarctic section only, and Hathrometra only in the Arctic. Bathymetrically, the species inhabit moderate or comparatively shallow water toward each pole, but dip downward to a few hundred fathoms when passing under the tropics. The species of Bathycrinus of the B. carpenterii group (B. carpenterii, B. complanatus, and $B$. australis) have a distribution suggesting an intimate connection with this faunal division, while the same may be said of Calamocrinus and Ptilocrinus.

These zoogeographic areas, outlined by the most sessile of all marine organisms, have a certain value as showing the primary distribution of life upon the sea-floor, with the minimum of secondary influences, such as ocean currents and the like. A comparison of the distribution of the crinoids with that of the sea-urchins, the star-fish, and the brittle-stars, shows the difference between practically sessile organisms, and related forms with a free-swimming period of more or less duration, and which are, therefore, more or less susceptible to the influence of currents and other marine phenomena. A careful comparison between the distribution of the deep-sea echinoderms will probably throw considerable light on the question of the deep currents of the ocean areas.

The bathymetric distribution of the crinoids, particularly in relation to their size, and the local distribution of certain species, both geographical and bathymetrical, offer many points of very considerable interest.

It has long been known, in regard to Antedon bifida of the coasts of Europe, that specimens taken in deep water are larger than those taken in shallow water, but no plausible reason has been shown for this phenomenon. It has been suggested that the coldness of the deeper water may stimulate it to greater development; but specimens from different localities, taken at a considerable difference in depth but with the same bottom temperature, will vary greatly, those from the greater depth averaging much the larger; similarly, specimens from the same depth, but with a considerable difference in the bottom temperature, will be found to be of practically the same size. Specimens from very shallow water are usually about 120 millimetres in expanse, and from deep water about 220 millimetres, or nearly twice as large, so there must be some factor of great importance brought to bear.

The food of crinoids consists of very small pelagic organisms and minute crustacea ; at or near the surface a crinoid must depend upon those which swim 
within reach of its pinnules, or which it may intercept by the slow motion of its arms, but in deeper water, while this source of supply is just as available as at the surface, the crinoid gete, in addition, all the carcases of those which die in the upper levels and fall to the bottom. The intensity of this rain of food increases, of course, proportionately with the depth, so that the deeper a crinoid lives, the greater is the available food-supply; consequently, the better nourished is the individual, and the greater is its size.

The increase in size, proportionate with increase in depth noticed in Antedon bifida, therefore appears to be in correlation with the increase in its food supply, and to be a direct result of it. Passing from a single species to a consideration of the group as a whole, it is found that (excluding the large littoral species of the tropics) the average size gradually increases from the shore-line to about the 100fathom mark; this is plainly due to the increase in the food-supply, as just explained: from 100 fathoms to about 600 fathoms the same size is maintained; but below 100 fathoms plant life, and with it the host of small organisms upon which (as well as upon certain of the minute plants) crinoids are dependant for food, begins to disappear. This gradual disappearance of vegetable organisms is offset by the gradual increase in the rain of carcases from above, so that an equilibrium is maintained down to about 600 fathoms, and hence the size of the crinoids remains practically stationary from the 100 to the 600 fathom line. Below 600 fathoms the gradual decomposition of the rain of carcases progressively le.seas its food value, and, therefore, a decrease in the size of the crinoids is noticed, scarcely perceptible at first, but soon becoming more marked, until, below 2000 fathoms, we find only the minute comatulid Bathymetra, and the equally tiny Bathycrinus, and Hyocrinus.

By this hypothesis, the general absence of the recent pentacrinites above 100 fathoms is at once explained. The stalked pentacrinites are animals of very considerable size; besides a bulky crown they have a large stem which must be nourished, and the organisms found at or near the surface of the sea are not sufficient; it is not until a depth of approximately 100 fathoms is reached that the organisms in the water about them, plus the cumulative effect of the rain of dead from above, acquires sufficient intensity to admit of their existence. Incidentally their remarkable uniformity in size is also explained, for the pentacrinites inhabit almost exclusively the 100-600 fathom zone, which has just been' shown to be a zone of uniform crinoid size. A species of Endoxocrinus, E. wyville-thomsoni, and the peculiar Hypalocrinus both descend to over 1000 fathoms; but both are much smaller than their relatives above the 600 -fathom line.

The common Arctic comatulid Heliometra glacialis (= eschrichtii) occurs from east of the Kara sea westward to west of Greenland, thence southward to Nova Scotia; the southern part of the sea of Okhotsk, and the northern part of the sea of Japan, I found to be inhabited by a variety, maxima, differing only in its great size from Arctic specimens. This species varies greatly throughout its wide range; north of Europe it is small, though rather larger around Spitzbergen; off Halifax, and on the Grand Banks, it reaches a comparatively large size; while off the western coast of Greenland it attains a diameter of 500 millimeters or more, reaching upwards of 700 millimeters in the Okhotsk and Japan seas. The west coast of Greenland abounds in fjords which are continually giving off fresh-water ice, which floats off, melting as it goes, thereby killing millions of small organisms which are unable to endure a great change in the salinity of the medium they inhabit; these organisms fall to the bottom, and furnish an abundant supply of food for the crinoids there, which consequently are enabled to attain very considerable dimensions. In the Kara and Barents seas there is no such supply of fresh water at hand, hence the 
crinoids are small ; but Spitzbergen, through its snowfields, resulting in the freshening of the water about it, allows the crinoids about its shores to reach a larger size than those of the Barents and Kara seas, though they are not nearly so large as are those from West Greenland.

On the Grand Banks, the Gulf Stream brushes by, and mixes more or less with, the cold northern current; this is fatal to the delicate southern life it contains, which is thereby killed and precipitated to the crinoids below; they, therefore, in spite of their living on the southernmost limit of the territory inhabited by the species, are as large as, or larger than, specimens from Spitzbergen.

The Kuro-Shiwo, or Japanese current, sends off a branch through the Korean straits which washes the eastern shores of the Sea of Japan, and in its northern part, from the straits of Tsugaru to the straits of La Pérouse, mingles with the very cold water from the Okhotsk sea. The mixing is very gradual, and extends over a very considerable territory, and over all this area the crinoids are of gigantic size, bearing witness to their enormous food supply. Now this colony of Heliometra glacialis var. maxima, a purely Arctic species, surrounded in the Pacific by widely different forms, and finding close relatives no nearer than the Kara sea, might be supposed, in the course of the centuries which have elapsed since the Okhotsk sea was a part of the Arctic ocean, to have become rather widely differentiated from the parent stock, and to have attained a very large adult size from some other cause than food-supply; fortunateiy, we are able to make some observations on other species bearing directly upon the point. In this area Heliometra is found where the bottom temperature is very low, about freezing, or below; but, dovetailed into these cold areas are others where the bottom temperature is $40^{\circ} \mathrm{Fahr}$., or above, at the same depth. These warmer areas are inhabited by an entirely different fauna, and we find in them entirely different crinoids, belonging to the purely Pacific genera Thaumatometra and Psathyrometra. It is gratifying to note that the representatives of both these genera are far larger here than anywhere else, the difference, in fact, being relatively greater in both these genera than in Heliometra; the three genera are living at the same depth, but at different temperatures and among entirely different surroundings, but their food-supply, coming in a rain from above, is the same, and is, moreover, the only common ecological factor; therefore there is no room for doubt that the food-supply is the cause of the great increase in size.

While the recent pentacrinites as a rule live below 100 fathoms, in certain places, such as in some localities along the northern coasts of Cuba and Guadeloupe, off Amboina, and in Suruga gulf and Sagami bay, Japan, they approach much nearer the surface, having been taken in from 20 to 30 fathoms (Guadeloupe). Now Cuba Guadeloupe, and Amboina, are mountainous islands, while Sagami bay and Suruga gulf are close to that magnificent mountain Fuji-yama, and to other high land as well. The result is that many intermittent streams flow into the sea at these places, having their origin in the high lands, and the rise in the volume of the fresh water is so sudden that the pelagic life cannot give way before it, but is killed and precipitated. The greatly increased food supply in the vicinity of one of these streams thus brings the food intensity up to such a level, that the large pentacrinites may exist in such localities in much shallower water than would otherwise be possible. The water from these streams is never very great in amount, and does not penetrate deeply, but spreads out over the surface of the sea; thus a crinoid could exist very near the surface without being at all affected by it. The large rivers, on the other hand, freshen the entire sea for a great distance from their mouth, and thus render crinoid life impossible.

Within the tropics, particularly in the East Indies, very large comatulids belonging to the families Tropiometridæ, Zygometridæ, Himerometridæ, and 
Comasteridæ occur abundantly in very shallow water, often just below the low-tide mark. Moreover, these decrease in size with depth. This would appear to directly contradict the conclusions reached in the case of Antedon bifida, but in reality entirely different factors are involved. Within the tropics the intense sunshine causes rapid evaporation from the surface of the sea, especially where the water is somewhat shallow, and a consequent mortality among the more delicate organisms ; the beaches and rocky shores at low tide warm up, to be covered again at high tide with comparatively cool water, full of organisms unable to stand a great change of temperature, which are therefore killed and swept back into the sea, to fall just beyond the low-tide mark. Periods of intense sunshine are relieved by torrential rains, which are just as fatal in their effect on small pelagic life. But torrential rains are associated with mountainous districts; a glance at the distribution of the species of these four families shows that all the large species, and practically all the small ones, occur exclusively about mountainous islands, or near high mainland, and they are particularly abundant along the shores of the larger East Indian islands. On isolated coral reefs and about the shores of low coral islands, where, owing to the low altitude of what little land there is, the rainfall is very small, these large littoral crinoids are quite absent.

The beautiful and brilliant coloration of the crinoids has often been remarked; so striking is the common European species, Antedon bifida, that it has been the subject of more coloured plates than any other echinoderm; Heusinger, Gosse, Dalyell, Dujardin, and Dujardin and Hupé have figured it in its natural hues; but the larger tropical species are much more varied and handsome, and are, for the diversity of their colours and the delicacy of their markings, unrivalled among the marine invertebrates. But the rapidity with which the colours fade after death has made it difficult for one not acquainted with the animals in their native habitat to understand them, as the only coloured plates of exotic species are those of Dr. W. E. Leach and Kuhl and van Hassett, of the comatulids, and Filhol and Alexander Agassiz of the stalked forms. There are, however, numerous records published of the colours in life, and a study of these brings out certain facts of considerable interest. In addition to these published records, I have been so fortunate as to have studied in life nearly one hundred species belonging to nearly all the known genera.

All colours are found in the crinoids, except blue, though black is confined to the disks of the Pentametrocrinidx, and to lines and spots on two species of Coccometra from the West Indies; blue and black, however, enter commonly into combination.

Crinoid colours may be grouped as follows :-

$$
\begin{aligned}
& \text { I. Yellow }\left\{\begin{array}{l}
+[a, \text { blue }]=\left\{\begin{array}{l}
a . \text { white. } \\
\beta . \text { green. }
\end{array}\right. \\
+[b . \text { black }]=\gamma . \text { brown. }
\end{array}\right. \\
& \text { II. Red } \quad \begin{cases}+[a \text { blue }] & =\left\{\begin{array}{l}
a . \text { purple. } \\
\beta . \text { violet. }
\end{array}\right. \\
+[b . \text { black }] & =\gamma . \text { crimson. }\end{cases}
\end{aligned}
$$

Yellow is the colour of all the more primitive forms and many of the more specialized throughout life, and is the colour of small specimens and of pentacrinoid young of comatulids, with very few exceptions. It probably represents the absence of colour in the group, as it does in the parrots, where the albinos are yellow instead of white as in other birds.

Red, in reality an intensification of the yellow, is the colour of all young which are not yellow.

The black factor in coloration is merely the result of age, and nothing more; all 
full-grown crinoids become dusky, sometimes to so great a degree as to obscure the original colour, except members of certain genera which are always and invariably clear yellow.

The blue factor is absent from all crinoids living below 150 to 200 fathoms, but, in the group as a whole, gradually increases in amount from that point to the surface; the first effect of blue is shown in whites and purples, which, as it becomes more intense, change to greens and violets.

Many crinoids exhibit the two basic colours, red or yellow, only; others exhibit these only, but may have more or less of an admixture of black. All crinoids below the limit of light penetration belong to one or other of these classes ; thus the deepsea forms are yellow, brown, red, or crimson. Of the shallower-water species, some are fundamentally yellow, some fundamentally red; the former will be found white, green, brown, or yellow; the latter purple (which may deepen to a dark maroon) violet (which may be almost blue), crimson, or red.

Some shallow-water species, such as Antedon bifida, are some specimens yellow, others red, from the earliest manifestations of colour. These when adult will be white, green, brown, or yellow, or any combination of these, or purple, violet, crimson, or red, alone or in any combination.

While this explains the coloration of all crinoids starting from an entirely yellow or entirely red base, certain forms are mosaics, that is, have primarily a mixture of both bases. These mosaics are of two classes; in the first, though both bases are found in the same species, they never occur together; specimens are always either fundamentally red, or fundamentally yellow; Tropiometra afra, occurring either yellow or violet, is an example; in the second, both bases occur in the same individual, which is therefore parti-coloured, as Tropiometra carinata, which is violet, with yellow blotches of greater or less extent; the latter class, however, always exhibits a tendency toward the former arrangement.

Their analysis of the coloration explains the wide range of hues found in these animals; they appear to be merely the result of light, which introduces a blue factor, on a pigment primarily yellow, more rarely red, plus the effect of the age factor, black. Not only the crinoids, but all the echinoderms appear to obey this law.

A short sketch has been given of the more obvious relations of the crinoids to the ocean currents, to light, to fresh water, and to land areas. Much more might be said ; but it is sufficient for the purpose of this paper to show the apparent intimate connection between this strictly marine and almost wholly deep-water group, and geography, in the hope that this line of study, by which many geological problems may be elucidated, will in the future be followed by those interested in the marine invertebrates.

\section{NEW INSTRUMENTS FOR TRAVELLERS AND SURVEYORS.}

\section{By E. A. REEVES, F.R.A.S.}

The following is a brief description of three instruments $\mathrm{I}$ have recently designed for the use of travellers and surveyors.

1. The Distance-finder Alidade for a Plane-table.-This is a light and portable form of the distance-finder described in the Geographical Journal for April, 1908, arranged so as to serve the purpose of a telescopic plane-table alidade as well as for finding distances. It consists of an aluminium ruler, $2 \frac{1}{2}$ feet long, at each end of which is fitted a small telescope placed at right angles to the ruler. One telescope 